\title{
Extranodal intraosseous Rosai-Dorfman disease in the lower jaw: a case report and review of the literature
}

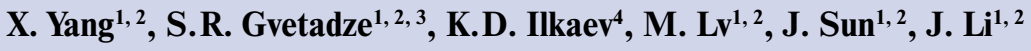 \\ ${ }^{1}$ Department of Oral Maxillofacial - Head Neck Oncology, Ninth People’s Hospital, Shanghai Jiao Tong University School of Medicine; \\ 639 Zhizaoju Road, Shanghai 200011, China; \\ ${ }^{2}$ Shanghai Key Laboratory of Stomatology \& Shanghai Research Institute of Stomatology, National Clinical Research Center \\ of Stomatology; 639 Zhizaoju Road, Shanghai 200011, China; \\ ${ }^{3}$ Central Research Institute of Dental and Maxillofacial Surgery, Ministry of Health of Russia; 16 Timura Frunze St., \\ Moscow 119991, Russia; \\ ${ }^{4}$ N.N. Blokhin National Medical Research Center of Oncology, Ministry of Health of Russia; 24 Kashirskoe Shosse, \\ Moscow 115478, Russia \\ Contact: Jun Li 13636616199@163.com
}

Rosai-Dorfman disease or sinus histiocytosis is a rare entity which may affect various lymph node groups. Extranodal form is observed in $45 \%$ of cases, facial bone involvement is especially rare. A 62-year old male presented with complaints on dumb sensation of the chin and lower lip. After clinical assessment and surgical exploration an intraosseous extranodal Rosai-Dorfman disease was diagnosed. The patient underwent free fibula osseous graft reconstruction. After 2 years the patient is recurrent free. The purpose of this publication is to describe a rare case of lower jaw involvement in an intraosseous form with significant bone destruction. The clinical and microscopic features of the process are discussed.

Key words: Rosai-Dorfman disease, sinus histiocytosis, mandible reconstruction, dull chin syndrome

For citation: Yang X., Gvetadze S.R., Ilkaev K.D. et al. Extranodal intraosseous Rosai-Dorfman disease in the lower jaw: a case report and review of the literature. Opukholi golovy $i$ shei $=$ Head and Neck Tumors 2018;8(2):34-8.

DOI: $10.17650 / 2222-1468-2018-8-2-34-38$

\section{Экстранодальная интраоссальная болезнь Розаи-Дорфмана в области нижней челюсти: описание клинического случая и обзор литературы}

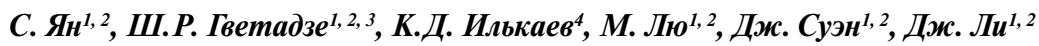

${ }^{1}$ Отделение онкологии полости рта и области головы и шеи, 9-й народный госпиталь, Медицинская школа

Шанхайского университета Дзяо Тун; Китай, 200011 Шанхай, шоссе Джидзяодзю, 639;

${ }^{2}$ Шанхайская ключевая лаборатория стоматологии и Шанхайский исследовательский институт стоматологии;

Национальный клинический исследовательский центр стоматологии; Китай, 200011 Шанхай, шоссе Джидзяодзю, 639;

${ }^{3}$ ФББУ «Центральный научно-исследовательский институт стоматологии и челюстно-лицевой хирургии» Минздрава России;

Россия, 119991 Москва, ул. Тимура Фрунзе, 16;

${ }^{4}$ ФБУ «Национальный медицинский исследовательский центр онкологии им Н.Н. Блохина» Минздрава России;

Россия, 1154784 Москва, Каширское шоссе, 24

Болезнь Розаи-Дорфмана, или синусный гистиоцитоз, - редкое заболевание, которое поражает различные группы лимфатических узлов. Экстранодальная форма наблюдается в 45 \% случаев, при этом кости лицевого черепа вовлекаются в процесс особенно редко. Мужчина, 62 лет, обратился с жалобами на онемение подбородка и нижней губы. После клинического обследования и хирургического лечения в объеме расширенной биопсии была диагностирована экстранодальная интраоссальная форма болезни Розаи-Дорфмана в области нижней челюсти. Проведена отложенная реконструкция свободным васкуляризированным костным лоскутом малой бериовой кости. Спустя 2 года наблюдения признаков рецидива не отмечалось. Цель публикации - описание редкого случая поражения нижней челюсти со значительной костной деструкцией. Обсуждаются клинические и микроскопические признаки данного патологического процесса.

Ключевые слова: болезнь Розаи-Дорфмана, синусовый гистиоцитоз, реконструкция нижней челюсти, синдром онемевшего подбородка

Для цитирования: Ян С., Гветадзе Ш.Р., Илькаев К.Д. и др. Экстранодальная интраоссальная болезнь Розаи-Дорфмана в области нижней челюсти: описание клинического случая и обзор литературы. Опухоли головы и шеи 2018;8(2):34-8. 


\section{Introduction}

Rosai-Dorfman disease (RDD) or sinus histiocytosis with massive lymphadenopathy was first described by P. Destombes in 1965 and further deeply researched by J. Rosai and R.F. Dorfman [1, 2]. In most cases this benign condition manifests with pseudolymphomatous proliferation of the sinusoidal histiocytes in the regional lymph nodes. Cervical lymph nodes are most commonly involved though numerous cases of mediastinal, axillary, inguinal and retroperitoneal nodal group disease were reported [3]. Clinically in most cases this leads to bilateral, painless lymphadenopathy which may be anticipated by febrile incidents with elevated white blood counts. Extranodal lesions are observed in $45 \%$ of the affected subjects [4]. These extranodal cases are not associated with lymphadenopathy and may present with several locations concomitantly or as solitary lesions. Among extranodal sites most familiar are the digestive tract, upper airways, orbit, skin and long bones [5-7]. Definitive diagnosis is established with pathological and immunohistochemistry exam.

In the present paper we describe a patient, who presented with complaints about unilateral sensory deficiency in the area of mental nerve innervation and proved to bear intraosseous Rosai-Dorfman disease of the mandible.

\section{Case report}

A 62-year old male patient was referred to our department with complaints on prominent continuous numbness of the right half of the lower lip which was persistent for more than 5 months. Before admission he was observed and treated in another institution. The symptom of numbness was suspected to be caused by the roots of right mandibular $3^{\text {rd }}$ molar compressing the mandibular canal. After the tooth was removed the numbness did not resolve and got accompanied by diffuse unceasing numb pain of the right mandible. After 5 months of symptom onset he presented in our department and with a non-tender, painless swelling at the right mandibular angle area. In the right mandibular body, the panoramic radiogram revealed a massive lytic medullary defect occupying the zone of the body between the mental symphysis and the extracted lower right third molar (fig. 1). Computed tomography (CT-scan) of the head and neck exhibited massive destruction of the mandibular buccal cortical plate and extensive homogenous soft tissue extension to the vestibular buccal side (fig. 2). The borders of the soft tissue component appeared smooth without signs of invasion to the surrounding tissues while the whole right mandibular canal appeared completely destructed with comparatively irregular bony edges. Clinically a soft and painless mass could be palpated intraorally along the right vestibule and extraorally in the lower right buccal area measuring a $6 \times 5 \mathrm{~cm}$ in size. Mouth opening was not limited. Sensory probes showed signs of neural deficit in the right mandibular and mental nerve innervation sites while other sites of trigeminal nerve innervation were unaffected. Blood tests as well as erythrocyte sedimentation rate were all normal and there was no associated pyrexia.

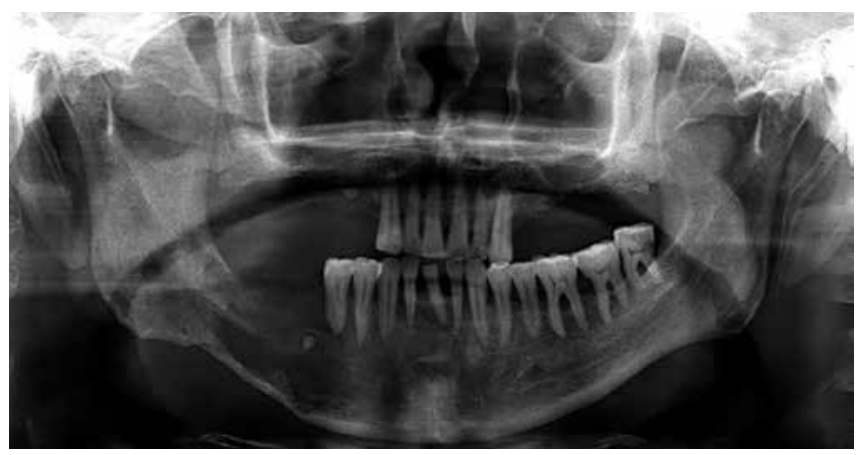

Fig. 1. Panoramic radiogram exhibits right mandibular body lesion. Both the basal bone and the alveolar crest are significantly destroyed

Рис. 1. Панорамная рентгенография, демонстрирующая поражение нижней челюсти справа. Значительное разрушение базальной кости и альвеолярного гребня

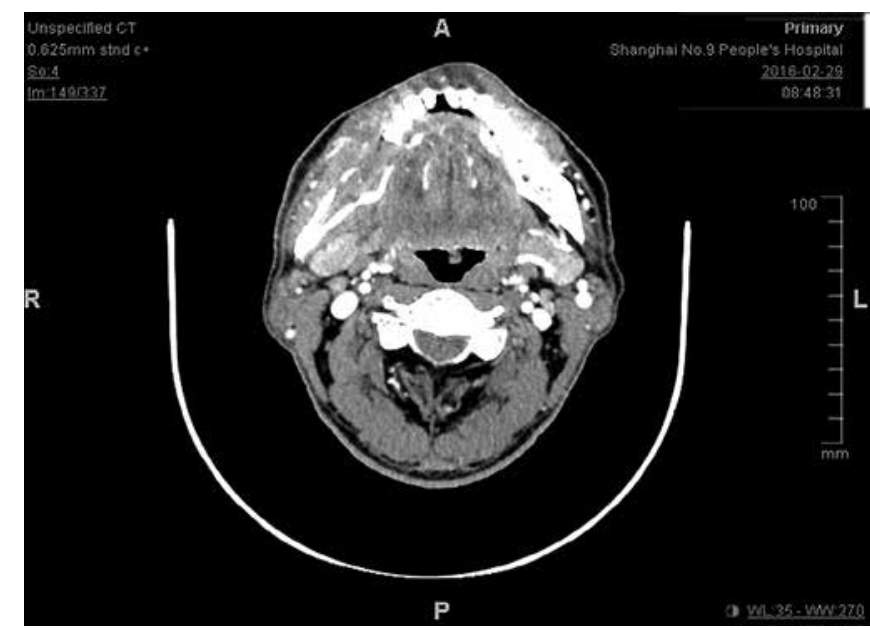

Fig. 2. Transverse view of preoperative computed tomography scan. Lingual and vestibular cortical plates lack continuity

Рис. 2. Предоперационная компьютерная томография в трансверсальной плоскости. Разрушение кортикальных пластинок с язычной и вестибулярной сторон

Differential diagnosis workup addressed several conditions which are capable to involve both, bone and soft tissues and included squamous cell carcinoma, lymphoma, malignant ameloblastoma, osteosarcoma and Langerhans cell histiocytosis.

During surgical exploration a pale, flashy connective tissue-like mass was exposed, the right mandibular body partially destructed, especially the alveolar crest. Exams of 2 consecutive frozen sections failed to make definitive diagnosis and referred to the picture as an unspecific inflammatory process with plasma cells, lymphocytes and vast number of histiocytes. Segmental resection of the mandible with temporal titanium plate fixation was carried out while secondary reconstruction was postponed until a pathological diagnosis is done.

Microscopic analysis showed prominent histiocytic proliferation with phagocytosis of lymphocytes and plasma cell, a condition which is termed emperipolesis and is a characteristic morphologic feature of the RDD (fig. 3). Immunohistochemistry 


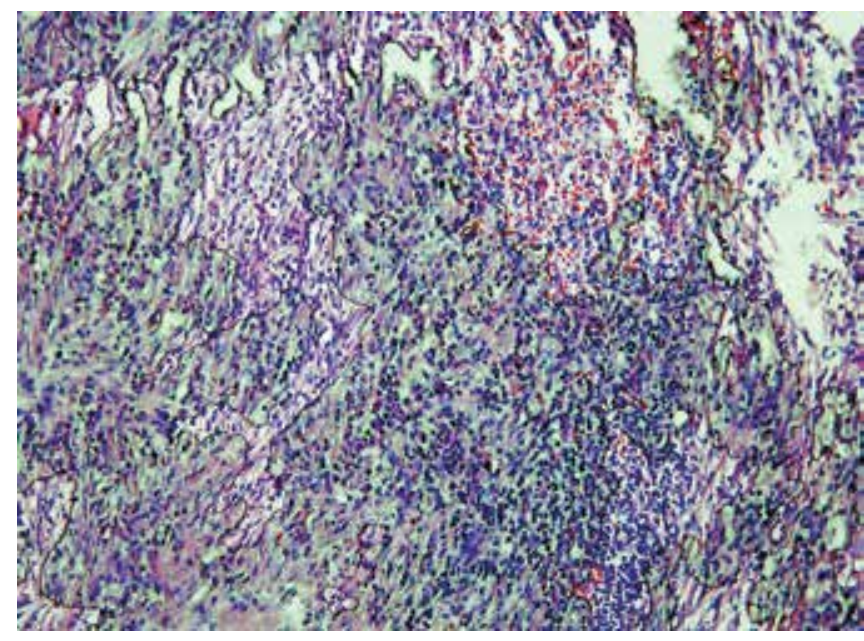

Fig. 3. The paraffin serial step section shows foci of histiocytic proliferation with phagocytosis of lymphocytes and plasma cell

Рис. 3. Серийные парафиновые срезы демонстрируют очаги пролиферации гистиоцитов с фагоцитозом лимфоцитов и плазматических клеток

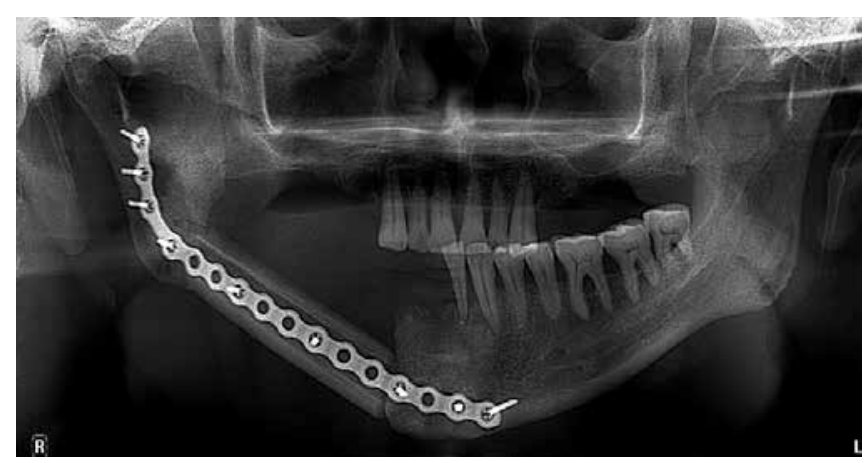

Fig. 4. The defect is reconstructed with free vascularized fibula osseous graft Рис. 4. Реконструкция дефекта с использованием свободного васкуляризированного костного трансплантата малой берцовой кости

staining was positive for $S-100$ and $C D-68$ and negative for $C D-1$ and Factor XIII confirming the diagnosis. The patient underwent reconstruction with a vascularized free fibula graft (fig. 4). No signs of recurrent disease were observed throughout 2 years of follow-up.

\section{Discussion}

RDD is a benign idiopathic disease which was initially described to affect lymph nodes. Subsequently after first presentations it became evident that this process may evolve in extranodal location with no associated lymphadenopathy. Osseous structures are seldom affected and more commonly lesions of long bones are described [7]. More than $70 \%$ of the extranodal RDD are seen in the head and neck region [8]. Facial bones affection rate is reported to be low, being less than $8 \%$ of all cases $[9,10]$.

When considering manifestation of the RDD the symptoms can be clearly divided into general and local. General symptoms (pyrexia, weight loss, leukocytosis, high erythrocyte sedimentation rate) are commonly exhibited in the classic form of RDD with lymphadenopathy. Extranodal form with localized connective tissue mass provokes local symptoms, associated with gradual expansive RDD enlargement while general manifestations can be omitted. Intraosseous RDD both in long or facial bones usually produces pain. Intraosseous maxillofacial RDD tend to manifest with dull diffuse pain preceded or accompanied by numbness in areas of trigeminal nerve innervation. Teeth vitality in the affected area is maintained though the growing mass can to provoke dental mobility and/or root resorption. A small number of cases describing mandible involvement are available [4, 11-13]. Of these only 1 patient presented with a generalized RDD form with bilateral cervical, axillary and inguinal lymphadenopathy, and local intraosseous RDD of the maxillary, mandible and zygomatic bones [11]. Radiologic features of RDD bone involvement are heterogeneous and range from well-outlined regularly bordered conglomerates to infiltrative lesions with ill-defined borders with or without periosteal spicule reaction $[6,7,14]$.

Microscopic and immunohistochemical analysis remains the pillar of RDD diagnosis. One characteristic morphologic finding of the disorder is emperipolesis. As defined by J.G. Humble et al. (1956) emperipolesis is "the active penetration of one cell by another which remains intact" [15]. In RDD histiocytes have a round nuclei with distinct nucleoli and abundant amphophilic to eosinophilic granular or clear cytoplasm. Immunohistochemistry exhibits qualities of antigen presenting cell or Langerhans cell (S-100 positive) and phagocytic histiocytes ( $\alpha_{1}$-antitrypsin, lysozymes, CD-68, MAC-378 positivity and CD-1a negativity) [16]. Recently touch imprint cytology was suggested as a reliable diagnostic alternative for an open excisional biopsy technique for intraosseous RDD [7].

Extranodal intraosseous RDD may be considered fairly rare entity in the maxillofacial region. Several descriptions of facial bone involvement can be found in the literature, more often orbital and sinus disease is reported. The processes in these locations can hardly be categorized as true intraosseous RDD because bony destruction, if present, is secondary to the soft tissue mass growth. In cases when both soft tissue and bone engrossment are observed at referral a careful combined interpretation of the radiologic data with clinical symptoms onset, duration and severity is critical for establishing if the lesion is truly intraosseous (or "primary" intraosseous) or the bone destruction is due to compression of the soft tissue mass. From this aspect the case presented here can be termed as truly intraosseous with soft tissue extension. Primarily the patient complained about the onset of numbness at the lower lip which was followed by painless check swelling only a considerable time later. Secondary according to the CT-scans, a massive bone destruction is present, especially the cortical plates. Such rate of both cortical and marrow bone abolition is much less likely to be caused by a slow extraosseous mass growth, if compared to primary intraosseous location of the RDD with 
its gradual expansive enlargement. The so called dumb chin syndrome was the first and the only manifestation of the intraosseous mandibular RDD as in most of the reported lower jaw involvements. This suggests that RDD is another lymphoproliferative neoplasia which should be included in the differential diagnosis of the dumb chin syndrome [17].

Treatment strategies which are advocated in the literature tend to depend on the form of the disease. Corticosteroid-based schemes are currently prescribed and are reported to be effective in cases of nodal RDD or extranodal disease without bone involvement [18]. Exceptional observations of steroid-resistant extranodal soft-tissue RDD were shown to benefit from radiotherapy [19]. On the other hand, surgical management either in form of conservative curettage or radical resection is generally chosen for intraosseous RDD. If performed properly surgical treatment assures excellent prognosis though cases of recurrences were outlined [20].

\section{$\begin{array}{lllllllllllllllllllll}\text { J } & \text { И } & \text { T } & \text { E } & \text { P } & \text { A } & \text { I } & \text { У } & \text { P } & \text { A } & \text { I } & \text { R } & \text { E } & \text { F } & \text { E } & \text { R } & \text { E } & \text { N } & \text { C } & \text { E } & S\end{array}$}

1. Rosai J., Dorfman R.F. Sinus histiocytosis with massive lymphadenopathy: a newly recognized benign clinicopathologic entity. Arch Pathol 1969;87:63-70.

2. Rosai J., Dorfman R.F. Sinus histiocytosis with massive lymphadenopathy: a pseudolymphomatous benign disorder. Analysis of 34 cases. Cancer 1972;30(5):1174-88. PMID: 5083057.

3. Suster S., Cartagena N., CabelloInchausti B., Robinson M.J. Histiocytic lymphophagocytic panniculitis. An unusual extranodal presentation of sinus histiocytosis with massive lymphadenopathy (Rosai-Dorfman disease). Arch Dermatol 1988;124(8):1246-9. PMID: 3401030.

4. Wenig B.M., Abbondanzo S.L., Childers E.L. et al. Extranodal sinus histiocytosis with massive lymphadenopathy (Rosai-Dorfman disease) of the head and neck. Hum Pathol 1993;24(5):483-92. PMID: 8491488.

5. Aoyama K., Terashima K., Imai Y. et al. Sinus histiocytosis with massive lymphadenopathy. A histogenic analysis of histiocytes found in the fourth Japanese case. Acta Pathol Jpn 1983;34(2):375-88. PMID: 6741550.

6. Hamels J., Fiasse L., Thiery J. Atypical lymphohistiocytic bone tumour (osseous variant of Rosai-Dorfman disease?). Virchows Arch A Pathol Anat Histopathol 1985;408(2-3):183-9. PMID: 3936259.

7. Pendse A.A., Wobker S.E., Greene K.G. et al. Intraosseous Rosai-Dorfman disease diagnosed by touch imprint cytology evaluation: a case series. Diagn Cytopathol 2018;46(1):83-7.
DOI: $10.1002 / \mathrm{dc} .23802$

PMID: 28834636.

8. Naidu R.K., Urken M.L., Som P.M. et al. Extranodal head and neck sinus histiocytosis with massive lymphadenopathy. Otolaryngol Head Neck Surg 1990;102(6):764-7.

9. Foucar E., Rosai J., Dorfman R.F. Sinus histiocytosis with massive lymphadenopathy (Rosai-Dorfman disease): review of the entity. Semin Diagn Pathol 1990;7(1):19-73. PMID: 2180012.

10. Carbone A., Passannante A., Gloghini A. et al. A review of sinus histiocytosis with massive lymphadenopathy

(Rosai-Dorfman disease) of head and neck. Ann Otol Rhinol Laryngol 1999;108(11 Pt 1):1095-104. DOI: $10.1177 / 000348949910801113$. PMID: 10579239.

11. Günhan O., Finci R., Günaydin Y., Somuncu I. Sinus histiocytosis with massive lymphadenopathy: a case with facial bones involvement. J Oral Maxillofac Surg 1991;49(2):205-9. PMID: 1990100.

12. Alawi F., Robinson B.T., Carrasco L. Rosai-Dorfman disease of the mandible. Oral Surg Oral Med Oral Pathol Oral Radiol Endod 2006;102(4):506-12. DOI: 10.1016/j.tripleo.2005.10.071. PMID: 16997119.

13. Tekin U., Tüz H.H., Günhan O. Reconstruction of a patient with RosaiDorfman disease using ramus graft and osseointegrated implants: a case report. J Oral Implantol 2012;38(1):79-83. DOI: 10.1563/AAID-JOI-D-10-00056.1. PMID: 20553156.
14. Xu Q., Fu L., Liu C. Multimodality imaging-based evaluation of RosaiDorfman disease in the head and neck: a retrospective observational study. Medicine (Baltimore) 2017;96(51):e9372. DOI: 10.1097/MD.0000000000009372. PMID: 29390533.

15. Humble J.G., Jayne W.H., Pulvertaft R.J. Biological interaction between lymphocytes and other cells. Br J Haematol 1956;2(3):283-94. PMID: 13342362.

16. Rastogi V., Sharma R., Misra S.R. et al. Emperipolesis - a review. J Clin Diagn Res 2014;8(12):ZM01-2. DOI: 10.7860/JCDR/2014/10361.5299. PMID: 25654060.

17. Smith R.M., Hassan A., Robertson C.E. Numb chin syndrome. Curr Pain Headache Rep 2015;19(9):44. DOI: $10.1007 / \mathrm{s} 11916-015-0515-\mathrm{y}$. PMID: 26210355.

18. Lai K.L., Abdullah V., Ng K.S. et al. Rosai-Dorfman disease: presentation, diagnosis, and treatment. Head Neck 2013;35(3):E85-8. DOI: 10.1002/ hed.21930. PMID: 22083607.

19. Maklad A.M., Bayoumi Y., Tunio M. et al. Steroid-resistant extranodal RosaiDorfman disease of the cheek mass and ptosis treated with radiation therapy. Case Rep Hematol 2013;2013:428297. DOI: $10.1155 / 2013 / 428297$. PMID: 23738161.

20. Shemen L., D'Anton M., Klijian A. et al. Rosai-Dorfman disease involving the premaxilla. Ann Otol Rhinol Laryngol 1991;100(10):845-51. DOI: $10.1177 / 000348949110001011$. PMID: 1952653. 


\section{Authors' contributions}

X. Yang: clinical data summary and article design;

S.R. Gvetadze: article writing and article design;

K.D. Ilkaev: reviewing of publications of the article's theme, manuscript editing;

M. Lv: clinical data collection;

J. Sun: manuscript editing;

J. Li: article design, clinical data collection, manuscript editing.

Вклад авторов

С. Ян: обобщение клинической информации и дизайн статьи;

Ш.Р. Гветадзе: написание текста статьи и ее дизайн;

К.Д. Илькаев: обзор публикаций по теме статьи, редактирование рукописи;

М. Лю: сбор клинической информации;

Д. Суэн: редактирование рукописи;

Д. Ли: дизайн статьи, сбор клинической информации, редактирование рукописи.

\section{ORCID of authors}

S.R. Gvetadze: https://orcid.org/0000-0003-3806-9022

K.D. Ilkaev: https://orcid.org/0000-0002-6225-663X

ORCID авторов

Ш.Р. Гветадзе: https://orcid.org/0000-0003-3806-9022

К.Д. Илькаев: https://orcid.org/0000-0002-6225-663X

Conflict of interest. The authors declare no conflict of interest.

Конфликт интересов. Авторы заявляют об отсутствии конфликта интересов.

Financing. No grants were issued for financing of the study.

Финансирование. Исследование проведено без спонсорской помощи.

Informed consent. The patient gave written informed consent to the publication.

Информированное согласие. Пациент дал письменное информированное согласие на публикацию своих данных. 